\title{
Influence of Culture on Workers Productivity in Nigeria Contexts
}

\author{
${ }^{1}$ Nwankwo Clement, ${ }^{2}$ Rev. Mbata Azumah .I. \\ ${ }^{1}$ Department Of Sociology, Faculty Of Social Sciences, University Of Port Harcourt \\ ${ }^{2}$ Department Of Human Kinetics And Health Education P.M.B. 5323, Choba, Port Harcourt, Rivers State, \\ Nigerian
}

\begin{abstract}
The greatest challenge facing human resource managers in recent years is how to ensure that the organization's demand for labour meets its projected needs and the supply of labour to the enterprise is maintained by deliberate and systematic action to mobilize it in reasonable balance with these demands. This paper examine the influence of culture on workers' productivity in an organizational setting, because of the influence of culture the attitudes of workers, it is considered here as an important environmental factor that should not be ignored in the study of workplace industrial relations. In spite of the abstract nature of culture, it still exists in a structural form. A particular important attributes of culture in the contexts of industrial relations that behavior is the means through which culture constitutes a dominant causal factor in the formation of attitudes which form the basis of behavior in organization. Therefore it becomes imperative for human resource managers to develop organizational culture that will embrace, regulate and motivate workers towards achieving optimum productivity in the organization. The study also review how industrial relation practitioners could identity and use cultural attitudes to understand the structural variables and structured relationships, institutions and rules of employment, and conflict resolution in the maintenance of industrial harmony in the organization.
\end{abstract}

\section{Introduction}

Before the establishment of British rule in Nigeria, there was no system whereby one depended for his livelihood on paid employment nor were there crafts or factories that depended on paid employees for their operation. The introduction of employer-employee relationships is not yet a hundred years old in most parts of Nigeria. Before then work was carried on individual and families or cooperate groups. Farming, which was the most important occupation, was carried out in household units comprising men, wives and children. Cooperation by neighbouring farming households or age grades in joint working parties for the preparing, planting and harvesting of their several plots was a general practice. Occasionally relatively wealthier farmers would request a whole kindred group, age-grade and in-laws to help them in farm work. The decision to grant such a request was unanimously arrived at by the group concerned. The farmer to whom help was given offered no financial reward except that he fed the workers and gave them wine at the close of work. The decision to undertake community work was arrived at by consensus in a community meeting which all adult males were eligible to attend and contribute to the debate.

The Nigerian's nonchalant attitude to organisational work may have to do with his lack of identification with and commitment to organisational goals which he regards as someone else's goals. Mr. Ukpabi Asika, the former administrator of the defunct East Central State regarded it as the greatest impediment to productivity and motivation.

When the British came and started to employ people for pay, those who were so employed in Igbo land were said to be doing the 'white-man's work' (Olu Oyibo). It did not matter whether the person was employed as a cook in the white-man's house or as a worker in the coal mine, railway. Civil Service, trading company, school or church: he was doing the 'white-man's work'. At the end of the Civil War (1967-1970). Asika thought that if he changed the name to Olu Obodo (community work) people would realise that they no longer worked for the white man but for themselves and would thereby change their attitude to work by transferring their positive identification with community work to work in the Civil Service and parastatals. The name was changed without any corresponding change in attitude. Why? Because there is nothing in modern organisational work that resembles community work, Ocho (1982).

It is clear today that there is a desperate need in Nigeria to develop effective management in industries and organisations of both private and public sectors. This need developed out of the realisation that the industrialisation and development of Nigeria greatly depends on the existence of an efficient, dedicated, involved and productive workforce. Various attempts to develop this type of workforce have not yielded fruitful results. Perhaps, the institutionalised orientations and attitudes of Nigerian management personnel towards performing their managerial functions may be a major contributing factor. Curious observers of Nigerian managers and supervisors at work have consistently described them as rigidly autocratic, egoistic, corrupt and 
selfish in their operations. They are said to be vehemently ethnic group-oriented, fanatically religious, hysterically conditioned to striving for eternal life, traditionally preoccupied with the satisfaction of basic lowerorder needs, and colonially brain-washed into developing a foreign mentality and a hedonistic view of life which regards money as the only source of luxuries.

In view of Nigerian managers, effectiveness as a manager is achieved maintaining the master-servant, rider-horse relationship which they inherited from former colonial rulers; by strictly using the company-derived, artificial powers to 'enforce policies and to obtain compliance, and by being strict, vigilant and serious with workers at all times. To workers, the manager must always appear tough; he must make all the decisions, issue orders and commands, and take ruthless actions against defaulters. Any failure or unwillingness by a supervisor to maintain these despotic postures is interpreted both by workers and management as a weakness. Thus, allowing subordinate participation in decision-making processes, delegating to them some authority and responsibility, and being sympathetic to their feelings, needs and problems, is seen by supervisors and managers as lowering oneself to the level of workers. They strongly feel that doing these things will weaken the manager's power and will make him lose influence and respect.

It my opinion that the understanding of feelings and attitudes of workers is central to the issue of improved management of human resources. Attitude to work is used here to mean disposition towards organisational work, feelings with regards to the concepts of responsibility, fairness, legitimacy in connection with the demands and rewards of organisational duties.

Analysis of various organisational theories and empirical investigations carried out in America and Europe cannot adequately explain the average Nigerian attitude to work. The typical Nigerian policeman, teacher, doctor, engineer, postal clerk and others can be relied upon to be 'lousy', 'nonchalant' and 'lackadaisical' in his organisational duties. On the other hand, when self-employed, he can be relied upon to be responsible, industrious, highly motivated and untiring; therefore, Human Resources practitioners should adopt measures that will felicitate workers moral in achieving efficiency in organization goal.

\section{Problem Of The Study}

The environment of productive activities in Nigeria is determined both by society and government. The extended family system exerts its own toll on the productivity of labour. The fact that each worker, on the average has to bear responsibility for a number of unemployed and unemployable relations puts some stress and strain on him which are not conducive to high productivity; Government's policies and legislations can be equally discouraging to both management and labour. When directors of parastatals are appointed for political, ethnic and other reasons which have no direct bearing on the experience and ability necessary for managing such establishments or when promotions are based on considerations other than efficiency, productivity of labour is adversely affected. These practices generally demoralize the worker and impede progress. In the same manner, legislative measures or a lack of such measures do affect productivity. The absence of a strong programme on family planning policy has affected not only the supply of labour but also the effective performance of a segment of labour, particularly women.

Another negative factor in the Nigerian polity is the way the constitutional principle of federal character is being implemented. Instead of being used to engender a broad sense of participation among all Nigerian ethnic groups, it became a vehicle for ethnic chauvinism and discrimination. Its role today has been to aggravate the sense of social injustice and discourage hard work and diligence especially in the public sector. The principle has today become antithetical to the promotion of merit, and this needs to be corrected. Worse still, Nigerians have tended to confuse merit with paper qualification, which it is not. Therefore, this is clearly an area where the country needs to make some deliberate and overt effort to reconcile merit or track record of performance with federal character as a basis for enhancing national unity and socio- economic development.

There is also the need for greater equity in the creation of national wealth as well as in its distribution. The over dependence of our economy on petroleum since the mid-seventies, and the consequent marginahisation of farmers and other primary-sector producers have to be rectified if labour is to once again assume a place of importance in the development of this nation.

The study noted that one of the most important factors militating against the development of this nation is the lack of effective leadership at all levels, even among organized labour. This lack of effective leadership to mobilise the norms and values positive to societal growth and development constitutes a major failing' in our national life. It is further aggravated by the frequent changes of government policies and the practice of changing our constitution, even when it is clear that such a change would not address seriously the fundamental problem of our underdevelopment.

Worse still, the style of life of each, generation of leadership, whether military or civilian, ends up alienating the workers and discouraging diligence and trustworthiness. Wrong people are often placed in important positions and no sanctions are exacted for their failures or malfeasance. 
The study noted with concern the repeated failures of such government parastatals as Nigeria Airways, the Nigerian Railway Corporation, NITEL and NEPA, when private sector-organisations, both national and multinational, are performing well. Why do public sector agencies fail while the private sector concerns manage to keep afloat? The infrastructural facilities for Nigeria's progress are certainly already in place, but somehow the country has been unable to make these effectively. It must be admitted that leadership in the country has failed if fifty three years after independence, the nation cannot change or amend any wrongs that were wrecked on its cult by their exposure to colonial influence. Insecurity, poverty, unemployment, strike of university lecturers for over four months, inability of payment 18,000 minimal wages since 2011 by some state government has prove that Nigeria state need total overhauling.

The study also noted that while from occasionally clamouring improvement in workers' pay and conditions of service, the Nigerian labour Congress (NLC) has been unable to take overt actions to discipline its members who run down the establishments where they work. It was observed that the NLC hardly openly condemns sabotage by its members, such as occurred with the damage of NEPA cables and machinery during the general strike of 1988. and 2012 fuel subsidy. Most Nigerian cultures set a premium on hearing both sides in a dispute and resolving conflict through dialogue.

Hence, there is the need to strengthen the Nigeria industrial labour relation culture which sets great store on a free flow of communication between management and workers to enhance the productivity of enterprises and the development of the country. It is essential that union leaders ensure that their members come to appreciate better the mechanism of dialogue and communication as a means of resolving industrial problems and enhancing productivity. They must also work closely with management to find ways of channeling our traditional values of honesty, hard work and community spirit to uplift the dignity and productivity of labour.

The dynamic interrelationship of all human organisations with their social and political environment must be recognised for a meaningful understanding of worker attitudes and behaviour. According to Katz and Kahn (1966, p. 22), the typical models in organisational theorising concentrate upon principles of internal functioning, ignoring external environmental influences as if they do not affect the maintenance inputs of motivation and morale.

Regrettably, the way in which organizations established differences in cultural attitudes influence the patterns of workplace industrial relations, the different cultural groups has hitherto been given little or no attention by researchers in the field of industrial relations.

\section{Theoreticl Framework}

Interpersonal and group similarity promote attraction, while dissimilarity is often a ground for dislike or out right disdain. Cultural attitudinal similarity are more important them physical similarity. Studies have indicated that we like people because they are like us or people whom we like are like us, Okpara, (1982:88). In other words, motivation has to do with a set of variable relationships that explain the direction, amplitude and persistence and an individual's behaviour. Similarly, Vroom (1964) defined motivation as a process governing choices among alternative forms of voluntary activity. Today there appears to be some agreement that a crucial characteristics of motivated behaviour is that it is a goal-directed choice.

The development of this theory is mainly the result of the work of Vroom and Lawler in the United State during the 1960's. A key thesis in this approach is that an individual's behaviours is formed not on some sense of objective reality but on this own perception of reality. The core of the theory relates to how a worker perceives the relationship between the three things - effort, performance and rewards. The strength of the attraction of particular outcome or reward for an individual is termed 'Valence'. The degree of belief that a particular act will produce a particular outcome is termed 'expectancy'. Valence and expectancies depend on the individual's own perception of a situation Ihejiamaizu (1996: 71-72).

Many social psychologist have studied common factors in human motivation, others have focused on differences between individuals. One such researcher, whose work is well known is D.C. McClelland of Havard University. He and his team have studied three basic needs in addition to physical needs. These are the need for affiliation belonging (b-Aff). In particular, McClelland has isolated n-Ach as a key human motive and one which is influenced strongly by personality and by environment. McClelland's position is that the need for achievement is developed more by childhood experiences and cultural background than by purely inherited factors. If this is correct, it has implications for management and supervisory training. If the need for achievement is influenced primarily by environmental factors, then clearly it is possible to develop training programmes designed to increase the development motive in the employees concerned, Iheiamaizu (1996: 71).

In another perspective, Talcott Parson's social system theory also emphasized the influence of culture in the sustenance of any organization, however, he propounded a theory call the AGIL. According to Parson, a function is "a complex of activities directed towards meeting a need or needs of the system". Using this definition, Parsons believes that there are four functional imperatives that are necessary for characteristics of all system - adaptation (A), goal attainment (G), integration (I), and latency (L), or pattern maintenance. Together, 
these four functional imperatives are known as the (AGIL) scheme. In order to survive, a system must perform these four functions:

1) Adaptation: It must cope with external situation exigencies. It must adapt to its environment in relation to its needs.

2) Good Attainment: A system must define and achieve its primary goals.

3) Integration: A system must regulate the interrelationship of its component parts. It also must manage the relationship among the other three functional imperatives $(A, G, L)$.

4) Latency (Pattern Maintenance): A system must furnish, maintain, and renew both the motivation of individuals and the cultural patterns that create and sustain that motivation, Ritzer (2008: 241) Paulsen and Feldman, (1995) disclose that the four action systems of Parson's (AGIL) illustrates that the behavioural organism is the action system that handles the adaptation function by adjusting to and transforming the external world. The personality system performs the goal attainment function by defining system goals and mobilizing resources to attain them. The social system copes with integration function by controlling its component parts. Finally, the cultural system performs the latency function by providing actors with the norms and values that motivate them to action.

From the forgoing, it is realized that the influence of culture can not be undermined if the organization is to attain its goals. It also become imperative that Human Resources practitioners to identify culture as a criterial in designing organizational structure which influence how workers participate in the production process, Nwankwo (2013.)

\section{Literature Review}

In the traditional Nigerian society, work is performed either on individual or communal basis. While a person may be indolent in the performance of individual work, he dare not be lazy in community work because he would be ostracised. There are proverbs in various Nigerian languages which stress that he who is lazy shall not eat. Nigerian traditional cultures, it was noted, extolled the virtues of hard work, honesty, truthfulness, community feeling of responsibility and accountability, and high moral standards. These cultures stress that only an honest day's work deserves an honest day's pay. There were sanctions to ensure honesty and the community sought to know the source of suspected wealth. Individuals were encouraged to regard themselves as their brother's keeper. Lazy people were ridiculed and even, ostracised. The exception perhaps were priests and priestesses who were allowed to live at reasonable level of comfort without much physical labour because they were believed to be busy communicating with the ancestral spirits and with the gods/goddesses to ensure the safety and prosperity of the workers, Olusegun and Mabogunje (1991).

The study took the view that the context of work and social justice at each period in Nigerian history must be examined closely. It was noted that before the colonial era, most people were self-employed and therefore saw the fruits of their labour as important. With colonialism came the system of wage labour, people no longer felt there were dignity in being a wage labourer or in paid employment with all the submission to the employers that it entailed. The sense of justice which gingered people to work hard at the community level broke down with the advent of colonialism and wage employment. Working for the colonialist became "Oyibo" or "European" work. A mentality developed that you dear not exert yourself too strenuously at such labour if it was to last and it was important that it lasted for a long time. In this way indolence gradually became a part of the culture of "labour" in colonial times. This mentality extended from government work to even private-sector employment. It was further compounded by a weakened attitude of honesty which was expressed in the surprising belief that, the good fortune of any individual can only come through extractions from some other individual's wealth. Hence there arose a practice where workers pilfered things from their work-places without compunction because they felt that the employers (the colonialists) were uninvited exploiters who carried away overseas, the gains from the fruits of their labour.

By independence, labour had become a part of the politically conscious group in the country. But rather than see the new government as its own government, it saw it as if it were still the distant colonial government that must be spiritedly confronted in the struggle for own welfare and improvement. Today, a major problem of the Nigerian society is how to change this negative attitude of Labor to government and to raise the low productivity which it engenders. In this regard, this study pointed out that: "productivity is (largely) an attitude of the mind It is a mentality of progress of the constant improvement of that which exists. It is the certainty of being able to do better today than yesterday and continuously. It is the continuous effort (by human beings managers and workers) to apply new techniques and new methods, it is the faith of human progress...." Olusegun and Mabogunje (1991).

However, it is possible to appreciate the enormity of the factors militating against the achievement of the highest level of productivity of the Nigerian labour. What is involved, in brief, is how to restore to the Nigerian labour the self-esteem which was eroded during the colonial era. 
Culture has long been recognised as an important determinant in the struggle for any country's socioeconomic development. In the literature of economic development, cultural inertia has been accorded a significant role and viewed as an active phenomenon. Sometimes, it is regarded as a sine qua non for socioeconomic development. Herskovits, for instance, states that any serious imbalance in the cultural congruity will mitigate against a society's development effort, Ejiofor and Aniogoh (1982).

In Western philosophical thinking, cultural determinism theorists: a subset of developmental economists, argue that there are development oriented values, the presence or absence of which aids or impedes the process of economic growth. Amlan Datta contended: for example, that hard work, a keen appreciation of time as a scarce resource and a code of honesty in business relations in one form or another are among the virtues essential to economic development, Ejiofor and Aniogoh (1982).

On the contrary, the impact of culture on the practice of management seems to have been relatively recent. It was not until the phenomenal economic growth of Japan that management experts started reasoning that cultural practice need not involve one-way traffic-the Western way. Japan, whose economic growth astonished the world, and whose health indicators such as infant mortality and life longevity are of Scandinavian proportions, achieved this envious feat with minimum social and cultural dislocation. It is contended that the pattern of social values and institutions which give rise to consensus and group collectivism in Japan is responsible for Japanese managers effective style of management.

Whilst the principles of management, as postulated by management experts have universal applicability. In practice, management often has to take into consideration and incorporate various factors that affect the workers' effectiveness on the job. One of the important factors in this regard is culture, for the practice of management is heavily influenced by the traditions, values and habits of a people.

In recent times, culture has been one of the most discussed topics in management circles. Some commentators have argued that the Nigerian culture is a 'disease' that acts as an impediment to the practice of effective management. Other writers have said that rather than being a disease, culture is in fact a 'cure' that should be used as a palliative for some of our colonial mentality hangovers. Culture has been defined by the anthropologists as '.... that complex whole which includes knowledge, belief, art, law, morals, custom, and any other capabilities and habits acquired by man as a member of a society'. Culture is an integral part of social life and it is the sum total of a people's way of life. It is prescribed by unwritten rules and standards which determine behaviour and attitudes. It is myopic to regard culture in terms of works of art, entertainment and dancing alone, because culture embraces the totality of the beliefs, attitudes and value systems of a society. An important characteristic of cultures is dynamism (as it comes into contact with other cultures) though the process of change is often a very slow one indeed, Titus (1982).

\section{Cultural Influences On Industrial Relations}

The study of the origins of diversities in the patterns of workplace industrial relations across societies has not hitherto received much attention from researchers in the field of industrial relations nor in the social sciences generally both in Nigeria and abroad, Ahiauzu (1982).

We should first note that industrial relations are personal and institutional relationships in the process of managing human resources in organisations. Management involves orientation, training, appraising and advancing, compensating and motivating the workers. It also involves maintaining workers physically and attitudinally, and finally integrating them for cooperation to higher productivity and industrial harmony. Management of human resources is the function of all managers at all levels, whether they are managing production, marketing or service processes. All managers therefore play the role of managing personnel and relationships at work. They are all concerned at varying levels in industrial relations. The influence of culture comes into the management of our social, political and economic organisations and, therefore, into industrial relations, if the ideology of the Nigerian traditional leadership is applied, if managers at all levels take up managerial positions based on proven merits, it is the proven merit and success in their personal fields of endeavour that equip them with the capability to assume paternalistic obligations according to the circumstances of the situation.

The manager has to be vigilant to identify anomalies and peculiarities. It is difficult to prescribe hardand-fast rules for the manager regarding how to recognise the incidence of cultural barriers in organisational activities. However, quick perception and patience are qualities that would be advantageous to him.

A worker's sociological, religious, psychological and emotional maturity must be watched at all times by the manager. In the context of multi-national company, Ivey and Litterer in their joint research programme into the cultural differences in business, found that misunderstanding of the communication habits of people in other cultures is a cause of major organisational inefficiencies, Titus (1982).

Kerr (1973) argued that economic growth has a dominant impact on the substantive rules of the workplace and the general shape of the industrial relations system in a society, irrespective of the influence of culture and that of the policies of the elitist group that leads the industrialisation process. The authors suggest 
that technology will be the main force in economic development and will play a central role in shaping the industrial relations systems of industrial societies.

Dore (1973) attributed less central role to technology. He recognised that culture was likely to have influences on workplace industrial relations and on the general mode of work organisation. His general treatment of culture shows that he does not consider that culture deserves being given a prominent place in accounting for differences in the patterns of workplace industrial relations across societies.

Similarly, most of the well-known writers on Nigerian industrial relations, among whom are Yesufu, Akpala, Diejomaoh, Kilby and Damachi, have tended to ignore the likely effects of culture on the Nigerian system of industrial relations, both at the workplace level and at the national level. Such practice of giving a low regard to, or attempting to ignore totally the cultural influences on industrial relations and on the general mode of the organisation of work and employment relationships implies a theoretical position in which one assumes (1) that societies do not have a cultural aspect (which very few would accept), or (2) that culture has no consequence for organisational variables, or (3) that different cultural systems have the same consequence for these variables. (Child: 1981).

Obviously, the implication (1) is not true, because cultural anthropologists have strongly established that societies exist in cultural groups with distinctly different cultural characteristics. Implications (2) and (3) can only be valid if it can be shown that there are no differences in 'workers' and 'managers' patterns of attitudes and behaviour at the workplace in different societies. A great deal of evidence exists which strongly suggests that this is not so. For example, Haire (1966) in their study of attitudes and need satisfaction of about 3,600 managers in 14 countries, suggested that variations exist in managerial behaviour patterns in different cultural contexts, and McClelland (1961) has shown that people in different societies possess different levels of need for achievement, and that a society's level of need for achievement is culturally determined and is rooted in the society's child-rearing practices and religious values.'

\section{Labour And Productivity In Cultural Setting}

Although an attempt was made at the beginning of this paper to define labour as any human effort that improves, creates or adds value to other factors, it was observed that the supply of labour is usually determined by the population of the country, particularly those within the age group of 15 to 64 years. These are the economically active people whether or nor they are actually working. The 64 -year limit is of special relevance to work in the modern sector of the economy since it is assumed that beyond this age, the productivity of a worker diminishes and he needs to retire. However, for the self-employed people especially those engaged in the informal sector of the economy, work often continues until death or until the individual does not have enough energy for work.

Notwithstanding these distinctions, this paper also noted that in any country, labour also embraces groups which are not usually given adequate consideration. Such groups included the handicapped, the unpaid, the unorganized children, housewives, and the unemployed.

Handicapped people can make their own contribution to development if the society will accept rather than pity them. The International Labour Organization (ILO) convention recommended that abut $2 \%$ of employment in any country should be reserved for the handicapped. Although a party to the convention, Nigeria is yetl to give substance to this recommendation. A labour legislation to this effect needs to be enacted soon and various programmes developed to implement the provisions of such a legislation.

In the development context, labour per se is not important but the productivity of labour. It is the increased productivity of labour that serves as a catalyst in the process of development. For this to be achieved, labour must become more efficient and effective through acquisition of more and relevant skill.

Furthermore the rigid distinction between workers and management must be blurred if labour is to contribute its optimum to development. It is necessary to look at social stratification as a reality and its influence in workers attitude towards socialization at the workplace, the recognition of this process is important because it gives the management the opportunity to understand the divergent nature of workers and minimized conflict in the organization. Industrial conflicts need to be minimized by the routinization of good labour relations and the identification and greater use of the factors in our culture which make for better productivity of labour.

There is an erroneous assumption that productivity applies only to workers and not to those designated as managers. This notion is highly mistaken and should be discarded because the creation and improvement of value are intrinsic in labour productivity in all human activities whether involving bodily or mental effort. From this perspective, the distinction between labour and management should be seen more in terms of the roles played by individuals in the production process. How well both groups act their parts is also a function of the social environment of work.

It is also necessary to look at what need to be done beyond the attitudinal changes, to improve labour productivity in the country. These include changes in the human, technological, environmental, managerial and other factors which also determine labour productivity. The human factors include health-care, nutrition, 
housing, transport and educational (formal and informal) matters; that is, matters that directly concern welfare as well as skill acquisition and improvement, otherwise classified as elements of human resource development. The technological factors encompass the whole work situation including machinery available for work, and avenues for on- the- job training, improvement and re-training. There must be a proper articulation of set goals and targets to be attained with the use of machines within a given time frame. Generally there has been an absence of a yardstick for productivity measurement in Nigeria. Time and time-keeping which are crucial to any industrialised society are unfortunately treated with levity in the traditional Nigerian culture because of its background of essentially peasant production.

This paper observed that in order to increase the productivity of labour, attention should be paid to the proper induction of newly employed workers and the constant consultation of the total body of employees on matters of meeting production targets and schedules. Management should not wait until a crisis situation has arisen before engaging in a fruitful dialogue and consultation with the workers' union. The training and retraining of workers should also be taken seriously in both the public and private sectors of the economy. Research into better ways of motivating workers to achieve stated objectives must be carried out on a continuous basis. Replacement of old and obsolete equipment must be done as soon as economically feasible. Enterprises should subscribe to relevant local and international journals and encourage management and labour to read these as one important method of continuously upgrading their knowledge. For the much needed technological transfer to take place, there is the need for both management and workers to contentiously exchange ideas on how to improve the current level of knowledge and skills. The technologists who repair machinery and equipment 'should be encouraged to think of designing and fabricating spare parts, and to devise better ways of using machinery and equipment for greater efficiency. This is one way in which Nigerian enterprises can foster and nurture indigenous technology.

\section{Developing An Organizational Culture}

It is difficult to escape from the influence of the organization culture in any organization work, in discussing of various factors that contribute to, and are influence by, organizations, structures, the issue of culture has to be taken into account. In essence the culture of an organization is its dominant pattern of share beliefs and values. Morgan (1986), from a sociologist's perspective, described it as, 'shared meaning, shared understanding and shared sense making

Handy (1993), looking at organizations as management consultant, points out that : anyone who has spent time with any variety of organizations.. .will have been struck by differing atmospheres, the differing way of doing things, the differing levels of energy, of individual freedom, of kinds of personality.'

The important point about culture is that whilst there may be striking differences between organizations, there is a shared understanding achieves a dominance in the collective thinking of the members of the organization. Having said this, it is also to be accepted that within any single (dominant) culture, there are usually sub-cultures, which operate at a lower level of influence. As Morgan puts it: Just as individual in a \{national\} culture, can have different personalities while sharing much in common, so too with groups and organizations. Organizations are mini- societies that have their own distinctive patterns of culture and subculture ... such patterns of belief or shared meaning can exert a decisive influence on the organization to deal with the challenges that it faces. (p.121). The dominant culture that develops in an organization is primarily the predicts of the aims and method of its founders, or their successors in senior management, combined with their interaction with a variety of internal and external forces. Figure 1 illustrates some important interrelationships that both produce, and are deeply affected by, the organization's culture.

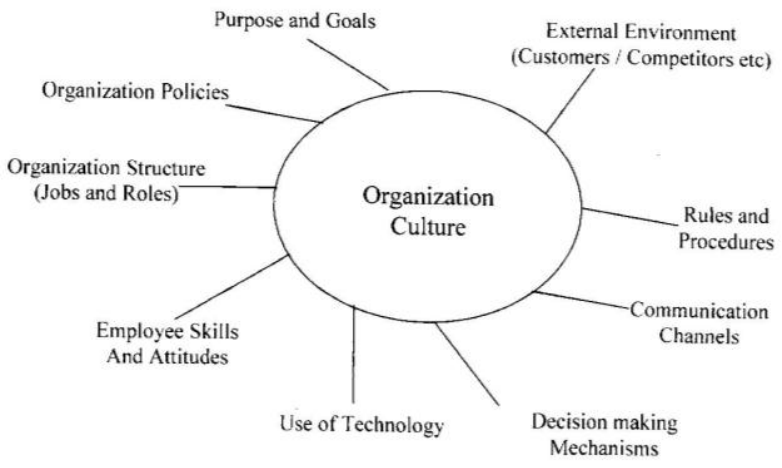

Key inter-relationships between culture and other aspects of an organization Source: Cole G.A. 1996:97 
The purpose and goals of the organization initially trigger the kind of culture that the founders or their successors want to see (their 'vision'). The extent to which they achieve this culture depends as much on the other factors as on their own leadership and charisma. The external environment will play a significant role, since customers, competitors, suppliers and other external stakeholders will all exert some influence on what the organization chooses to do, and how it will do it. Internally, the abilities and attitudes of employees, especially managers, will be critical. The nature of the technology available, and the way it is implemented in the organization, will also play a part in the development of culture. And, of course, on top of all these factors are the organizational structures, mechanisms and procedures that are a major part of the organization's fabric. The latter analogy is illuminating because it is helpful to think of the culture as being woven in between all the other factors, linking them together and producing a whole tapestry, Cole 1996.

\section{Organizational Culture And Management Innovation}

The expression 'culture', when applied to organizations, has come to mean the predominant system of beliefs and values held in an organization by its members. Schein (1985) defines 'culture' as follows:

...Pattern of basic assumptions-invented, discovered, or developed by a given group as it learns to cope with its problems of external adaptation and internal integration - that has worked well enough to be considered valid and, therefore, to be taught to new members as the correct way to perceive, think, and feel in relation to those problems.

A key feature of schein's definition is its focus on assumptions that is on implicit behaviour, rather than on explicit or overt behaviour, lie also stresses that culture is learned as a result of experience and suggests that it can be changed if we know the dynamics of the learning process.

It is probably useful to consider 'culture' as a two-tier set of shared values, norms and beliefs within an organization. On the surface is the explicit culture, which manifests itself in the way management itself is structured and in the rhetoric of bulletins, notices, etc. Beneath the surface lies an implicit culture, probably closer to reality, which resides in the assumptions made by management and staff about what really, is important.

A strong culture is one where the implicit and explicit assumptions are in harmony. A week culture is one where the implicit and explicit dimensions are at odds with each other.

The whole point of cultural change strategies is to achieve harmonization between the two tiers. Schein (1985) makes the interesting point that 'The function of culture in the life of the group changes as a group matures.' puts it: 'The forces that can unfreeze a given culture are also likely to be different at different stages of organizational development.

His view is that organizations pass through three major periods of this life- cycle:

- $\quad$ birth and early growth followed by a succession phase

- $\quad$ organizational mid-life

- $\quad$ organizational maturity followed by an alternative between transformation or destruction.

At each major period the culture has a different function to perform. For example, at the birth stage culture is 'the "glue" that holds the organization together'; at the succession stage, culture becomes the 'battle ground between conservatives and liberals'; at organizational mid-life the dominant culture 'becomes a constraint on innovation '. After the maturity stage, culture can be transformed in an evolutionary way, or can be destroyed and completely replaced 'through a massive replacement of key people', (2002).

Cultural and environmental diversity is a key issue in international HRM. As Halley (1999) remark:

In cultures where people are emphasize, it is the quality of interpersonal relationships which is important. In cultures where ideologies are emphasized, sharing common beliefs is more important than group membership. In cultures where actions are emphasized, what is done is more important than what is said.

Hofstede (1980) emphasizes that there are a number of cultural dimensions that affect international operation. His framework has been adapted by Bento and Ferreira (1992) to produce the following cultural dualities:

- $\quad$ Equality versus inequality;

- $\quad$ Certainty versus uncertainty;

- $\quad$ Controllable versus uncontrollability;

- Individualism versus collectivism;

- Materialistic versus personalization;

Sparrow and Hiltrop (1997) note the following HR areas that may be affected by national culture:

- $\quad$ Decisions on what makes an effective manager;

- $\quad$ Giving face-to-face feedback;

- $\quad$ Readiness to accept international assignment;

- $\quad$ Pay systems and different concepts of social justice;

- $\quad$ Approaches to organization structuring and strategic dynamics. 
Sparrow (1999a) gives examples of different approaches to managerial qualities. The Anglo-saxon sees management as something separate and definable, based on general and transferable skills, especially interpersonal skills, In Germany; an entirely opposite view is adopted: value is placed on entrepreneurial skills, technical competence, functional expertise and creativity, and managers rely more on formal authority than other Europeans countries. In France, management is seen as an intellectual demanding task and management development systems are elitist. Brewster (1999) comments that the 'universalistic' approach to HRM reverent in the USA is rejected in Europe where the basic functions of HRM are given different weights between countries and are carried out differently. If a convergent and therefore universalistic approach is adopted by a US international company, it might be difficult to get it accepted in Europe. Divergences to respect cultural differences may be more appropriate if the full potential of the overseas company is to be realized, Armstrong (2006).

The cultural differences mentioned above have produce the slogan 'think globally and act locally; this means that an international balancing act is required, which read to the fundamental assumption made by Bartleft and Ghoshal (1991) that:

'Balancing the needs of co-ordination, control and autonomy and maintaining the appropriate balance are critical to the success of the multinational company; Ulrich (1998) suggest that to achieve this balancing act, there are six capabilities that enable firms to integrate and concentrate international activities and also separate and adopt local activities:

1) being able to determine core activities and non-core-activities;

2) achieving consistence while allowing flexibility;

3) building global brand equity while honoring local customs;

4) obtaining leverage (bigger is better) while achieving focus (smaller is better);

5) sharing learning and creating new knowledge;

6) Engendering a global perspective while insuring local accountability.

International HR policies will deal with the extent to which there should be convergence or divergence in the HR practices adopted in overseas subsidiaries or unities. These will have to take account of differences in employment law, the character of the lab our market, different employee relations processes and any cultural differences in the ways in which people are treated, Ghoshal 2006.

\section{Summary}

In my view, the typical Nigerian worker today, is lazy, indolent or couldn't-care-less. He avoids work and responsibility, but loves money, wealth and all the good things of life. The Nigerian worker is materialoriented, pleasure-seeking and ego-centric and wants to get rich quickly. He loves social status and wants to be seen, recognized and treated with respect as the man at the head, in charge of affairs, the 'Oga'. He has a lust for power and authority and likes to be regarded as the source of power and authority, in fact, the typical Nigerian worker is not different in any fundamental way from the average Nigerian since he is simply a recruit from the wider society. But he is certainly different from workers of the Western world, who, as the need arises, are used as reference groups. The latter are more committed to stork.

The first, and perhaps the most important need of the Nigerian worker is a permanent job and a regular income. But unfortunately, he is also an impatient riser. As soon as he enters an organization, he wants to get to the top quickly. Even if he is unqualified, he hates to be a messenger or a clerk-someone on the lower rungs of the ladder. Rather, he looks up to the position of an officer, a boss. And if he is qualified, he believes that he deserves to be a supervisor, a manager, a director, a chairman, a senior lecturer or a professor, the head of a department or the chief executive. The implications of these tendencies are far-reaching. For instance, Nigerians now know that a good job carrying good status depends upon paper qualification. For many, especially the unscrupulous, the easiest way is to secure the certificate by any means. Alternatively, job security and promotions could be achieved by malpractices. Merit, experience, capability, efficiency, responsibility and duty are then de-emphasised. Even where the clerk has accepted his position, he demonstrates, occasionally, the 'clerical power'. He can cause files and vital documents to go missing at crucial moments. Then he causes them to reappear only when he has been satisfactorily induced. A point seems to have been reached whereby work is merely an instrument for the satisfaction of needs and aspirations which bears no direct relationship with the roles and tasks performed by the worker. In fact, many of our workers would very much like to earn their wages by doing nothing. This explains, at least partially, the problem of 'attitude to work' as we know it today. In these circumstances, the task of human resources development is made much more difficult, especially when it is based on such parameters as motivation, responsibility, leadership and productivity, etc. 


\section{Conclusion}

The nature and formation of the Nigerian cultural super-structure have tremendous and over-arching influence on the sort of cultural policies that shape and direct our national development. The Nigerian state, it was argued, must strive to perpetuate those values and virtues that Nigerians have come to accept. The noticeable failure of our public institution to bring, to bear on their operations our established cultural practices needs to be consciously obviated. Virtually all of these institutions have over the years failed to reflect in their actions the social aspects of our cultural life like hospitality, politeness, warmth and courteous reception of people. The consequence has been a situation wherein civil servants and other state officials have become civil masters. Institutions under such civil servants have become associated with insensitivity, bossiness, uncaring attitude and insincerity. On the basis of the above discussions, the paper suggested that:

a) Our leadership should encourage our public institutions to apply our cultural values of hospitality, respect and sensitivity, to their day-to-day activities.

b) The State must show a greater interest in the development of our human resources and foster more opportunities for the retraining of workers.

c) The State should consciously promote the reading culture in the people.

d) Libraries should be established at all the levels of governance including the community level.

e) Schools should be encouraged to give books rather than cash as prizes in recognition of good performance by students.

f) Government should plan its activities in such a way that bottlenecks are removed from the process of delivering public services. Such bottlenecks are usually exploited by public servants to create opportunities for corruption, and by so doing, subvert our positive cultural values in public institutions;

g) States should review all ordinances that have negative impact on our culture.

In view of these, the Japanese society has managed to preserve its ingrained cultural practice of respect for elders, it regretted that Western education has diminished such traits in the Nigerian. The acquisition of literacy skills during the colonial period precipitated an inversion of values; such that, literate youths felt superior to the older and more illiterate persons much in the same way that the colonial officials felt superior to the indigenes. These are, therefore, the need to re-examine the values being inculcated in children in your educational system. Parents also need to pay more attention to the proper socialization of their children and to imbue them with the appreciation of the fine values and practices of our traditional culture.

\section{References}

[1]. Ahiauzu A.I. (1982), Cultural influence on industrial relations, Longman Nig. Ltd

[2]. Aniagoh V.A, Ejiofor P.N.O (1982) Managing the Nigeria Workers, Longman Nigeria Ltd.

[3]. Armstrong, A. (2006): A Handbook of Human Resources Management Practice, Philadelphia, PA 19147, USA.

[4]. Authur, E. (1995) Managing Human Resources in Small and Midsized Companies American New York. (2 edition).

[5]. Banjoko, S.A. (1996), Human Resources Management, An Expository Approach, Saban Publishers Lagos, Second Edition.

[6]. Baridam, D. (2002), Management Practice in Nigeria, Olakulim Press Ibadan.

[7]. Beach, D.S. (1970), Personnel; the Management of People at Work. Collier Macmillan Publishers London.

[8]. Bento, R.and Ferreira, L.(1992), Incentive pay and Organizational Culture in W Bruns(ed) Performance Measurement, Evaluation and Incentives. Harvard Business School press, Boston, MA

[9]. Brewster, C.(1999), Strategic Human Resource Management: the value of different Paradigms, in Strategic Human Resource Management, ed R. S. Schuler and S. E. Jackson, Blackwell, Oxford.

[10]. Bertlet, C. A, and Ghoshal, S.(1991), Managing Across Borders: The transitional Solution, London Business School, London.

[11]. Cole, G. A (1996), Management theory and Practice, Fifth Edition Martins the prints Ltd.

[12]. Cole, G.A (2002) Personnel and Human Resource Management, Bookpower.

[13]. Corroil, B and Tossi, P. (2002). Industrial Organization-Theory and Practice. O.U.P. Publisher.

[14]. Dore .R. (1973), British factory - Japanese factory George Allen and Unwn, London.

[15]. Fashoyin T. (1980), Industrial Relation in Nigeria, Meshico Enterprises Ltd.

[16]. Halley, J. (1999), Localisation as an Ethincal response to Internationalisation, in HRM: contemporary issues in Europe ed C. Brewster and H, Harris, Routledge, London.

[17]. Handy, C. (1993), Understanding Organization, $4^{\text {th }}$ edition, Penguin Business

[18]. Ihejiamaizu, E. C. (1996), Comprehensive Text Book in Administrative and Organization Theory, Executive Publisher, Calabar

[19]. Kessler S. and Bayliss F. (1992) Contemporary British Industrial Relations. Macmillan London.

[20]. McClelland (1961) Achievement motivation can be developed, Harvard Business Review.

[21]. Morgan, G. (1986), Images of Organization, Sage.

[22]. Nwankwo C. (2013), State Policies and Challenges of Industrial Relation in Nigerian, Siren Journals, Port - Harcourt.

[23]. Ocho L.O (1982), Cultural influence on work attitude, Longman Nig. Ltd.

[24]. Okpara E. (1982), How can we motivate the Nigeria worker, Longman Nig Ltd.

[25]. Ritzer, G. (2008), Sociological Theory, Macgraw Hill Companies.

[26]. Sparrow, P. R. and Hiltrop, J - M (1997), Redefining the field of Human Resource Management: a battle between national mindsets and forces of Business transition, Human Resource Management, 36(2) pp 201 - 19.

[27]. Sunday, E. D. (2012), The Applicability of Human Resource Forecasting in Nigerian, Hospital. CEDSAF Journals, Vol.7 No.1

[28]. Schein, E. H (1985), Organization, Psychology, $\left(3^{\text {rd }}-\right.$ edn $)$, Prentice Hall.

[29]. Ulrich, D (1998), A new mandate for Human Resources, Harvard Business Review, January - February, pp 124 - 34.

[30]. Titus A.O. (1982), The management of Culture for effective performance Longman Nig. Ltd.

[31]. Vroom V.H. (1964), work and Motivation, Wiley, New York. 